\title{
TOURISTIC MOTIVATION AND LIFESTYLES OF HUNGARIAN DOMESTIC TOURISTS CORRELATION STUDY
}

\author{
Csilla Kalmár-Rimóczi \\ Faculty of Economics and Business \\ Institute of Rural Development, Tourism and Sports Management \\ Szolnok Campus \\ E-mail: csilla.rimoczi@econ.unideb.hu
}

\begin{abstract}
Motivations are closely interwoven with personality theories. According to researchers the object of motivation theory is primarily to describe what is common in people, whereas lifestyle theories highlight the individual differences among people. Tourism travel decisions constitute a special type of consumer decisions in which case the tourist has to make a choice among the personal tourism services on offer according to his/ her individual needs, but still as a segment specific product corresponding to common motivations. Consequently, certain elements of lifestyle and motivation theory appear in touristic decisions as well. Having perused the relevant trade literature, I came to the realisation that there have been very little research done in the area of travel motives in recent years. The examination of the correlation between motivation and lifestyle complemented with model application is a field belonging to applied marketing science which can be regarded as uncharted territory in tourism research. Domestic tourism accounts for a significant portion among the national income sectors. That is why it is of key importance to be aware of the correlation between the habits and needs of the local population and the factors influencing travel decisions. Applying the results of my research I endeavoured to define and model the lifestyle, needs and motivations of domestic tourists as the factors influencing their decisions. With the results of the investigation, I also wished to provide some guidelines for the creation of tourism supply in view of product development and communication.
\end{abstract}

Keywords: Motivation, lifestyle, hungarian domestic tourism, correlation

(JEL Classification: Z32 tourism and development)

\section{INTRODUCTION}

The definition and interpretation of lifestyle is primarily related to sociology. Sociology offers two interpretations. One is that lifestyle reflects a kind of result and is a consequence of some social affiliation, position in the hierarchy. The other approach claims that lifestyle is an indicator of a given and coveted social status that you want to acquire and maintain.

The first definition of lifestyle in Hungarian can be linked to Max Weber (WEBER (1964)), who formulates two types of social stratification in his book: completing classes and estates that may be closest to lifestyle definition: “... classes are stratified by their relationship to production and acquisition of goods, while estates are stratified by the principles of commodity consumption represented by their particular lifestyles" (WEBER, 1964, p. 93). ). Max Weber does not refer to any group of lifestyles, but only treats the hands of ruling status groups as a means of power and power. UTASI (1984), SOBEL (1981). In his view, lifestyles can be interpreted in two dimensions: One dimension expresses lifestyle and is closely related to the way individuals live their lives, where their place in society is limited. The other dimension in the Surroundings is the outside world seeing consumers where their public behavior is perceptible.

Many researchers have attempted to define lifestyles, taking into account various aspects and factors. The first research on lifestyle and the resulting definition comes from Max Weber. An important mention and the following researchers are those who have defined lifestyle in various ways and who have sought to illegally use a system of consumer behavior. The scientific work of BELL (1958), Rainwater - COLEMAN - HANDEL (1959), HAVIGHURST - FEIGENBAUM (1959) lasted until the late fifties. Bell focused his attention on examining the relationship between consumption and consumer behavior. Rainwater, Coleman and Handel highlighted the importance and relationship between energy consumer behavior and lifestyle. The success of these scientific researchers remains constant, but the concept of lifestyle has not been precisely defined. LAZER (1963) for the precise definition of a published article which is widely accepted and accepted. In his view, the lifestyle system. This is the distinctive and distinctive purpose of life, which 
enables society to respect its segments. Shopping habits and consumer behavior realistically reflect individual lifestyles and lifestyles. (P. 130)

From a marketing perspective, KELLEY (1963) takes a close look at the concept of lifestyle. Not only do people sell and deliver consumer prices, they symbolize a consumer consumer price / consumer lifestyle. VEBLEN (1975) observes a way of life in observing the social elite. The sheer physical superiority of the prehistoric community, the bloodthirsty of the weaker individuals, and the preservation of its leadership constituted courage and heroism. Later, this theory changed. Opportunity and inactivity have begun to be largely represented, so these luxury items are only available if they are managed with enough wealth. Of course, this was a feature of the elite. By deploying the Industrial Revolution, the wealthy and knowledgeable social class can afford to buy luxury goods, making it a special energy use. Therefore, one's own consumer behavior represented and characterized a benevolent lifestyle.

In addition to the concepts described above, other attempts have been made to define the concept of lifestyle. It is believed that lifestyle cannot be described and described in a single word, and that it is a much more complex concept. The definition published by the researchers is a disclosure requirement for a variety of heterogeneous and uniformly contradictory characteristics, such as sociology and marketing research, which are not available to define the concept of lifestyle. This is understandable because the lifestyle reflects our public behavior, our values, our attitudes, our opinions, our personalities, and completely determines our consumer habits and behaviors.

The realization of the importance of lifestyle analysis and deeper research can be traced back to the early seventies. This is when the research begins to discover that the demographic characteristics used to analyze consumer behavior and identify lifestyle groups are inadequate. Other factors should be considered for everyone in order to better analyze consumer decisions and understand the underlying content factors behind them. The aim of the evolving psychographic analysis is consumer behavior, a deeper understanding of travelers in this article. Although researchers' opinions split over the elaboration of the particular models, methods, as well as their dimensions and details, in general it can be established that lifestyle research divides into two larger factions. The two groups are configured on the basis of what their research focuses on in respect to consumption. These two options are as follows:

- the FAMILY as consumption unit, and the exploration of its types;

- the INDIVIDUAL as consumption unit, and the recognition of its unique characteristics (VERES HOFFMANN - KOZÁK, 2009.).

Human needs are inexhaustible and become motivated at optimal intensity. An individual may have multiple demands at the same time, while being ranked among psychological characteristics and becoming individually derived from psychological stress. Referring to Maslow's "hierarchy of needs", it is likely that somewhere it is likely that recognition and recognition will require the e-category. After a while, it is needed and becomes motivated directly by the internal factors. Motivation motivates the individual to act through which the tension is reduced or completely eliminated. So motivation can be written with an inner feeling that encourages and enables motivation. In the same way as income and social status are determined, the individual occupies a place in the hierarchy, motivation definition and choice criteria (VERES, 2007).

There are many theories in the interpretation of motivation. In Sigmund Freud's psychoanalytic theory, the iceberg metaphor aims at the human mind; one part above water is responsible for conscious thinking, one part above water is responsible for conscious thinking. Why claim that people don't know what drives them. His soul-related speculations support the idea of thinking and testing, of having a soul choice, and of changing soul behavior. Defining Attitude Choice, We Predefine It (FREUD, 1923)

\section{OBJECTIVES AND TASKS}

\section{Basic objective}

The basic objective of the present dissertation is the description and characterisation of the travel behaviour of domestic tourists.

Additional objectives

- A review of consumer and touristic behaviour models that can be connected to the research theme, an examination of their applicability in the area of tourist consumer behaviour.

- By applying secondary research, an exploration of the characteristics of tourism in Hungary, a description of domestic travel habits of Hungarian citizens.

- By applying primary research, a description of the travel habits of the traveller sample surveyed, an exploration of the correlations between lifestyles, touristic motivations and other factors influencing travel decisions.

\section{Tasks to be solved}

Following the logic of theory - methodology - and empirical examination, the following tasks were defined:

From the theoretical aspect:

- Review of the relevant trade literature. The research extends into several fields of science including tourism, consumer behaviour, touristic behaviour, lifestyle research. Accordingly, the objective was to familiarize myself with and process the relevant national and international literature.

- A review of the factors influencing touristic consumer behaviour that have an impact on travel decisions and may provide foundation for the standardization of tourists. 


\section{Empiric research:}

- Secondary research: exploration of the characteristics of domestic travel of the Hungarian population.

- Primary research: exploration of the habits of the traveller sample surveyed, identification of the segments based on touristic motivation and lifestyles generated by the application of multivariate mathematical and statistical methods.

Research hypotheses

H1: It is hypothesized that the primary aim of the Hungarian population for domestic travel among the push factors is "rest and relaxation".

H2. The travel behaviour of individuals following different lifestyles is characterized by the use of different types of leisure tourism activities as primary motivation.

H3: Based on the sample surveyed, certain homogenous groups can be identified that are suited for the purpose of characterizing respondents according to their lifestyles.

H4: Based on the sample surveyed, certain homogenous groups can be identified that are suited for the purpose of characterizing respondents according to their touristic motivations.

H5: Belonging to different lifestyle groups have an impact on the travellers' different touristic motivations.

H6: Based on the demographic features of respondents, certain homogenous groups can be identified showing diverse touristic motivations and habits.

H7: The travel habits of individual demographic groups are defined by diverse characteristics of lifestyle, differing motivations and factors.

In the course of my research, I followed a sequence thoroughly developed and circumscribed earlier. The secondary research constituting the basis of the dissertation was complemented by primary research.

\section{METHODS OF DATA ACQUISITION}

Secondary research was started by processing the relevant works of Hungarian and international researchers in tourism and consumer behaviour. The works of illustrious representatives of Hungarian and international trade literature were used to ensure theoretical foundation for the theme. Furthermore, Hungarian and international tourism trade journals, and online publications on the theme available on websites were also employed to substantiate certain topics of the dissertation. The provision of up-todate information was also assisted by drawing from the tables of statistical databases. The information databases of CSO, UNWTO, and EUROSTAT provided the main indicators on tourism.

The examination and analysis of trade literature was followed by the exploratory research and test interviews. The survey was conducted through a questionnaire in the town of Szolnok in April 2016, at the venue of the Travel Expo. The respondents were selected by simple random sampling with the help of interviewers. Before the personal completion of the questionnaire, we employed the background variable that the respondent is the resident of Jász-Nagykun-Szolnok (JNSz) County, and typically travels from home for tourism purposes at least once a year. The objective of the questionnaire survey was to explore the travel habits of JNSz County residents for domestic leisure tourism purposes.

Additional objectives of explorative research were:

- Definition of the most important variables and correlations with the aim of further examination.

- Acquiring an overview for approaching the problem.

- Establishing priorities for further research.

After analysing and assessing the results of the exploratory survey, the content of the questionnaire was modified to achieve easier interpretation and analysis, and this modified version was used in 2017 for a comprehensive research involving 1,596 respondents. Because of the large sample, according to trade literature, it may be classified as a national survey (MALHOTRA, 2009).

The objective of the research employing a large itemnumber sample was to identify and characterize the travel habits of domestic leisure tourists and, furthermore, to explore possible correlations between their touristic motivations and lifestyle factors and the likely lifestyle groups generated based on these factors. The background variable employed was whether it was typical of the respondents to travel at least once for one night for leisure purposes from home. Primary attention was paid to what type of groups can be generated based on the particular touristic motives and lifestyle characteristics featured in the questionnaire and whether a correlation can be detected between the resulting touristic motivations and lifestyles.

The survey was conducted using three sources employing combined electronic and personal queries. The three methods and sources were as follows:

the questionnaires in google.docs format were sent to the e-mail address list of a domestic tour operator company,

university students were asked to get the paperbased questionnaires filled in by their acquaintances in the largest possible number,

online community sites were used to reach the audience who were able to give relevant answers concerning travel habits.

From the three sources, during a half-year period, 1,792 questionnaires were received of which 1,596 were fit for appraisal.

International trade literature offers a number of empiric research and results concerning the travel habits of leisure tourists. In these research the emphasis is often laid on the examination of the "push” and "pull” motivating factors. Nevertheless, several other factors are considered in examining how, and employing what means and methods, can the travel market be divided into homogenous groups. The travel habits of men and women, young people and students have all been examined. Beyond the classic 
factor and cluster analysis, complex explanatory models and methods were used to establish correlations between touristic motivations and satisfaction, touristic motivation and propensity to return (OOM DO VALLE, 2006; YOON - UYSAL, 2005).

In Hungary, a similar survey examining travel behaviour complemented by an analysis of the correlation between touristic motivation and lifestyle has not been conducted yet. Based on the above, using the international and national trade literature research as foundation, quantitative means and methods were employed to examine the travel habits of a section of the Hungarian population.

\section{RESEARCH RESULTS}

\section{Characteristics of domestic tourism}

The Hungarian Tourism Agency Zrt., and its legal predecessors, have systematically been examining the travel habits of the Hungarian population since 2003.

H1. It is hypothesized that the primary aim of the Hungarian population for domestic travel among the push factors is "rest and relaxation".

Performance of domestic tourism based on the 2016 annual report

For the verification of the hypothesis the 2016 annual report of the Hungarian Tourism Agency was used which contains an analysis of the performance of Hungarian tourism and the characteristic travel features of Hungarian households. The report serves as the most reliable data source for the analysis of the performance of tourism.

In 2016, almost half of the Hungarian population left their home for domestic travel at least for one day. The causes for not travelling were given primarily as scarce financial means, some health impediment and commitment to the job by the respondents.

Compared to the years 2014 and 2015, a slight setback could be detected in the number of several-day domestic trips. In 2016, Hungarians took 14.4 million several-day trips staying within their country. The main motivations for domestic travel were visiting friends and relatives (VFR), holidaying, entertainment, relaxation and some hobby-type work activity. Discounting VFR and hobby motivations, the number of leisure tourists increased by $3.4 \%$ compared to 2015. Altogether, Hungarians spent 58,967 thousand days travelling which was $4.9 \%$ less than in 2015-ben. For leisure purposes 58,122 thousand days $(-4.5 \%)$, for business purposes 750 thousand days $(-19.3 \%)$ were the total staying time among domestic travellers. The number of days spent by leisure tourists, not counting VFR and hobby motivations did not decrease, but showed a $2.7 \%$ increase. With the aim of holidaying, entertainment and relaxation 28,909 thousand days were spent; visiting relatives and friends accounted for 22,430 thousand days. Health preservation took up a total of 2, 638 thousand days, hobby-type work activities amounted to 2,288 thousand days; attending cultural or sports events came to 940 thousand days while school study trips and camp stays took up 917 thousand days (Table 1).

Table 1: Number of several-day domestic travel and length of stays according to main motivating factors

\begin{tabular}{|c|c|c|c|c|c|c|}
\hline Motivation & $\begin{array}{l}2-4 \\
\text { days }\end{array}$ & $\begin{array}{c}5 \text { and } \\
\text { more } \\
\text { days }\end{array}$ & Total & $\begin{array}{l}2-4 \\
\text { days }\end{array}$ & $\begin{array}{l}5 \text { and } \\
\text { more } \\
\text { days }\end{array}$ & Total \\
\hline & \multicolumn{3}{|c|}{ travel in thousand days } & \multicolumn{3}{|c|}{$\begin{array}{c}\text { length of stay in thousand } \\
\text { days }\end{array}$} \\
\hline $\begin{array}{l}\text { Holidaying, } \\
\text { entertainment } \\
\text { relaxation }\end{array}$ & 3671 & 2412 & 6083 & 12199 & 16710 & 28909 \\
\hline $\begin{array}{l}\text { Visiting relatives } \\
\text { and friends }\end{array}$ & 5525 & 935 & 6459 & 15895 & 6535 & 22430 \\
\hline $\begin{array}{l}\text { School study trip } \\
\text { or camp stay }\end{array}$ & 96 & 78 & 174 & 264 & 653 & 917 \\
\hline $\begin{array}{l}\text { Health } \\
\text { preservation }\end{array}$ & 500 & 128 & 628 & 1692 & 946 & 2638 \\
\hline $\begin{array}{l}\text { Cultural and } \\
\text { sports events }\end{array}$ & 245 & 43 & 287 & 675 & 265 & 940 \\
\hline $\begin{array}{l}\text { Hobby-type } \\
\text { work activities }\end{array}$ & 422 & 121 & 543 & 1317 & 970 & 2288 \\
\hline Official trips & 182 & 39 & 221 & 459 & 291 & 750 \\
\hline Other & 23 & 5 & 28 & 63 & 32 & 96 \\
\hline Total & 10664 & 3761 & 14425 & 32565 & 26403 & 58967 \\
\hline
\end{tabular}

Source: own editing based on CSO figures

The average overnight stays in case of domestic travel totalled 4.7 days (without VFR and hobby trips: 4.1 days). The longest stays typically resulted from school study trips and camp stays (5.3 days), though the overnight stays of travellers motivated by holidaying, entertainment and relaxation was also relatively high (4.8 days). In case of hobby-type work activities, the average time came to 4.2 days; health preservation was also 4.2 days; visiting friends and relatives: 3.5 days; business trips: 3.4 days; attending cultural and sports events averaged: 3.3 days. In 2016, in the course of several-day domestic travel, the Hungarian population spent a total of 308.9 billion forints, which represented a $0.5 \%$ increase compared to the 2015 figure.

The specific (one person per day) spending in the course of several-day domestic trips amounted to 5,239 forints (up by $5.6 \%$ ). The highest specific spending resulted from health tourism (8,993 forints), and was also typical of travellers motivated by holidaying and entertainment (7,296 forints). (In case of longer, four and more night stays, again the specific spending of travellers motivated by health tourism was the highest (7,086 forints). Examining the above figures, excluding the VFR and hobbytype motivations, it can be observed that leisure tourist spending 
in 2016, totalling 244.7 billion forints, grew by $3.7 \%$ compared to the previous year, while the specific spending reached 7,326 forints (up by 1.0\%).

Travel characteristics of Hungarian households based on the 2016 report

Among the main motivating factors behind the domestic travel of households, visiting friends and relatives was the most important: one-third (33.3\%) of the trips covered were motivated by this reason. Bathing, bathing in adventure pools featured as the main motivation in case of $19.8 \%$ of domestic travel, staying in holiday/second homes weighed in with $9.4 \%$, wellness holidays accounted for $7.6 \%$, while visiting historical towns and monuments followed with $6.8 \%$. The destinations in the first five places altogether made up for $76.9 \%$ of all the trips taken by households in 2016 (Table 2).

Table 2: Distribution of domestic travel according to the main motivation

\begin{tabular}{|l|c|c|}
\hline \multicolumn{1}{|c|}{ Main motivation of travel } & $\mathrm{N}$ & $\%$ \\
\hline $\begin{array}{l}\text { Visiting friends relatives, } \\
\text { acquaintances }\end{array}$ & 716 & 33,3 \\
\hline $\begin{array}{l}\text { Bathing, bathing in } \\
\text { adventure pools, visiting } \\
\text { aqua parks }\end{array}$ & 425 & 19,8 \\
\hline $\begin{array}{l}\text { Spending leisure time in } \\
\text { holiday or second homes }\end{array}$ & 203 & 9,4 \\
\hline Wellness & 163 & 7,6 \\
\hline $\begin{array}{l}\text { Visiting historical towns, } \\
\text { churches and monuments }\end{array}$ & 146 & 6,8 \\
\hline
\end{tabular}

Source: Characteristics of Hungarian households in 2016

The research also examined in detail what activities the members of the household were doing during the major trip as the main motive for the trip does not fully describe the character of the travel.

The respondents, where the background variable required that they also took part in the trip, were aked to select from a list the activities they completed during the trip.

In the case of major domestic travel, according to the allusion rate, the hierarchy of activities began with passive relaxation (66.7\%), closely followed by bathing, bathing in adventure pools and visiting aqua parks (65.2\%). $44.4 \%$ of households visited historical towns, $35.5 \%$ enjoyed meals in restaurants, inns, coffee shops and confectionaries, $21.8 \%$ visited friends and acquaintances, $20.6 \%$ made use of wellness services, $18.9 \%$ went on hiking trips, and $18.4 \%$ spent leisure time visiting castles and mansions. $15.4 \%$ attended festivals and other cultural programs and the same ratio is represented by visitors of wineries and cellars for the purpose of wine sampling.

H.1. This hypothesis was only partly verified. The primary domestic travel motivation of the Hungarian population is visiting friends, relatives and acquaintances. However, the primary travel activity pursued in the course of the trip is resting and relaxation.

Exploratory research: description of travel behaviour of residents of Jász-Nagykun-Szolnok County

In the questionnaire of my own design targeted at residents of Jász-Nagykun-Szolnok County. besides covering questions on general travel habits, specific questions focusing on the respondent's lifestyle and demographic characteristics were also featured. The target group of the survey was the traveller with permanent residence in Jász-Nagykun-Szolnok County, characterized by taking at least one trip per year with the aim of leisure tourism. The sample size was: 322 people.

The structure of the questionnaire was as follows:

- Is it typical of you to travel for touristic purposes: this background variable was employed to screen the people who are less likely to travel or do not travel at all.

- Two questions referred to the length and frequency of the trip. Several answer options were offered for the purpose of descriptive statistics.

- Assessment of other factors influencing travel decisions was done employing a scale of importance. The question was intended to assist the analysis of the impact of the most and least important factors.

- Statements of the VALS2 type questionnaire: included 34 statements. Respondents could indicate on a Likert scale how accurate the statements were in their respect. The responses were interpreted as group generating criteria for the categorization of a travelling lifestyle.

- Question group for the types of leisure tourism: Respondents were asked to mark the type of leisure tourism they took part in most frequently staying inland in the past few years. The question was meant to identify their primary motivation. The questionnaire featured the types of tourism that proved to be the most frequent travel motivation according to the 2016 performance report of the CSO. Respectively, among travel motivations, the leisure tourism types were selected and complemented with the most popular forms including sports, nature and rural tourism. Demographic questions were also included referring to sex, age, and highest qualification. The responses were used as group generating criteria for the purpose of further analysis and examination of correlations.

The exploratory survey was conducted using the questionnaire in the town of Szolnok at the venue of the Travel Expo in 2016. Respondents were selected by simple random sampling assisted by the interviewers. Before the personal completion of the questionnaire, we employed the background variable that the respondent was a resident of Jász-Nagykun-Szolnok County, and typically travelled from home for tourism purposes at least once a year. The objective of the questionnaire survey was to explore the travel habits of JNSz County residents for domestic leisure tourism purposes. A background variable was employed whether the respondent typically travelled for leisure at least once a year spending at least one night away from home.

The objectives of the test interviews via questionnaire were summed up as follows:

- Definition of the most important variables and correlations with the aim of further investigations.

- Acquiring an overview to approach the problem. 
- Establishing priorities for further research.

- Additional objectives:

- Exploration of the characteristics of domestic leisure travel habits of Szolnok residents.

- Lifestyle segmentation on the sample travel set.

- Definition of typical leisure tourism types corresponding to lifestyle groups.

Hypothesis based on the above objectives:

H2. The travel behaviour of individuals following different lifestyles is characterized by the use of different types of leisure tourism activities as primary motivation.

Consequently, it was hypothesized that travellers following different lifestyles would primarily prefer clearly identifiable types of leisure tourism. Based on the results gained, the primary motivations of the individual segments could be identified.

The results of the explorative survey served as foundation for further comprehensive research. For the purpose of gaining better results and completing further analysis, the questionnaire needed to be modified and made more accurate on the following points:

- Among the factors defining travel decisions motivation featured as the third most frequent influencing factor, therefore the analysis of the touristic motivation chosen as the theme of the research proved to be a relevant objective.

- The hypothesis that different lifestyle groups are characterized by pursuing clearly identifiable types of tourism did not prove to be true. Consequently, the understanding of further touristic motivations needed deeper investigation.

- In order to better understand touristic motivations and for the purpose of the correlation study constituting the theme of my research, the question group on tourism types was modified and divided into "pull' and 'push" question groups considering the motivations behind the decisions.

- In order to provide a wider demographic characterization for the individual lifestyle segments, a question on age was modified to age categories and the group-generating criteria were complemented with questions on income levels, economic activity and family life-cycle.

\section{COMPREHENSIVE RESEARCH: QUERY OF TRAVELLERS AIMED AT EXAMINING THE CORRELATION BETWEEN LIFESTYLE AND TOURISTIC MOTIVATION}

In the questionnaire of my own design targeted on the Hungarian population, besides the questions aimed at general travel habits, the respondents' lifestyles and demographic characteristics were also inquired about. Based on the experience gained, the questionnaire used during the exploratory survey was modified. The target group of the survey could be any individual who typically travels away from home with the purpose of leisure tourism at least once a year. Out of the 1,792 questionnaires completed, 1,596 were fit for processing and evaluation.

The structure of the questionnaire was as follows:

- Is it typical of you to travel for touristic purposes: this background variable was employed to screen the people who are less likely to travel or do not travel at all.

- Associative question: respondents were asked in an open question to give one word that comes to their mind when they hear the word 'tourism'. The aim of the question was to establish the positive or negative charge of the word.

- Two questions referred to the length and frequency of the trip. Several answer options were offered for the purpose of descriptive statistics.

- Assessment of other factors influencing travel decisions was done employing a scale of importance. The question was intended to assist the analysis of the impact of the most and least important factors.

- Statements of the VALS2 type questionnaire: included 34 statements. Respondents could indicate on a Likert scale how accurate the statements were in their respect. The responses were interpreted as group generating criteria for the categorization of a travelling lifestyle.

- Question group of touristic motivation: 64 „push” and "pull” touristic motivating factors assessed on a scale of importance expressing how important in general that motive was during a particular trip. The answers also served as group generating criteria for the purpose of setting up homogenous groups.

- Demographic questions referring to sex, age, permanent residence, highest qualification, economic activity, family life-cycle, and the category of net income per capita. The responses were used as group generation criteria for the purpose of analysis and examination of correlations.

\section{RESEARCH OBJECTIVES, HYPOTHESES, SAMPLE AND STATISTICAL METHODS}

The following were considered as research objectives:

1. The exploration of domestic travel habits, identification and generation of segments based on touristic motivation and lifestyle through the application of multivariate mathematical and statistical methods.

2. By employing primary research, characterisation of the travel habits of the sample surveyed, exploration of the correlations between lifestyle, touristic motivation and other factors influencing decisions.

The following research hypotheses were set up:

H3: Based on my sampling, certain homogenous groups can be identified that are characterized by their lifestyles.

H4: Based on my sampling, certain homogenous can be identified 
that are characterized by their touristic motivations.

H5: Belonging to different lifestyle groups has an impact on different touristic motivations.

H6: Based on the demographic characteristics of respondents certain homogenous groups can be identified showing differing touristic motivations and habits.

H7: The travel habits of individual demographic groups are defined by different lifestyle characteristics, different motivations and factors.

The sampling unit was defined as the population with residence in Hungary. Before the sampling, the background variable was applied that respondents travel at least once a year with the purpose of domestic tourism spending at least one night away from home.

The sample size was 1,596 people, which can be considered a national survey (MALHOTRA, 2009.). A simple random sampling was employed avoiding any laws. This provided an opportunity for any individual with residence in Hungary to complete the questionnaire without restrictions on age.

Causality relationships in the full sample

A description of the significant causality relationships in the path models was worked out from the full sample.

The verification of causality relationships was done with regression models. The methodology requirements were met in each causal relationship featured and described, namely:

- The regression models are significant (the significance level of the F-test: $p<0.05$ ).

- The explanatory variables of the model are significant $(\mathrm{p}<0.05)$.

- The standardised regression parameters (coefficients) are sufficiently high $(<0.1)$.

In the full sample, contrary to the conceptual model, none of the motivational factors had an impact on travel habits.

Figure 3: Comprehensive block diagram of the causality model derived from the four segments examined highlighting the differences between the groups

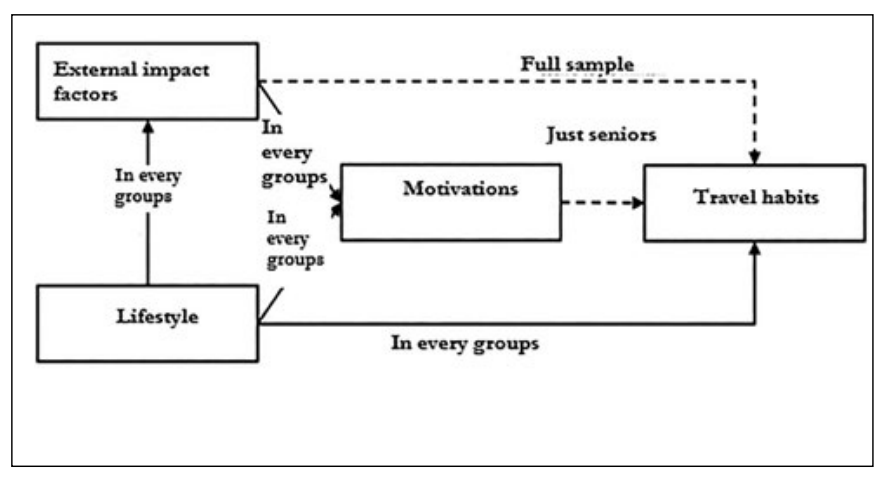

Sources: own desig

\section{CONCLUSIONS}

In the first part of my dissertation, through the processing of the relevant Hungarian and international trade literature, an overview was given of the system and characteristics of tourism, and the specific features of touristic demand and supply. The examination of the general features of consumer behaviour research was followed by the exploration of consumer behaviour in tourism, the tourists' motivation and behaviour habits.

On this basis the following conclusions have been drawn:

- An understanding and analysis of consumer behaviour is getting an ever greater attention in scientific research and practical applications since the key to successful marketing is a profound knowledge of the behaviour of potential buyers and consumers living in national or international cultures.

- Consumer behaviour is influenced by innumerable factors, and various research projects have identified and explained them in different ways.

- Touristic demand and the accompanying touristic consumer behaviour is an extremely complex process, since it is not a single product or service that is offered to the travellers and tourist, but some aggregate of them.

- The major part of the world's tourist turnover can be connected to leisure tourism. Its specific feature is that people travelling together are usually belong to a family or group of friends and less often to the workplace.

- They lifestyle, social composition of the world's population and the development stage of individual countries are in a constant flux. These changes, among others, make an impact on tourism and its performance, too. It is advisable to get prepared thoroughly for these changes affecting tourism well before they befall. Former marketing strategy policies have to be revised, and the changes in consumer behaviour and habits have to be followed.

- Travel decision is the outcome of a very complex process. The factors influencing the decisions have been described by researchers in many different ways employing numerous methods. Summarily, it can be noted about the impact factors that travel decisions are influenced both by the characteristic features of the individual and both the external factors independent of the tourist.

- Travel decision cannot be made without touristic motivation, since according to the principle of the threelegged stool, motivation is one of the most important "coercive" forces.

- A deeper investigation into the importance of lifestyles goes back to the beginning of the 70s. It was then that researchers started to realize that the demographic factors applied earlier to the analysis of consumer behaviour proved insufficient. In order to analyse consumer decisions and recognize and understand factors with deeper content behind the decisions, further factors had to be taken into consideration. 
The results of my own research, setting up new theses:

- The Hungarian Tourism Agency publishes a report on the performance of Hungarian domestic tourism very year. The accomplishments of domestic tourism can also be found in the database of the Central Statistical Office. Based on the data in the documents, it can be established that the primary touristic motivation for the Hungarian population in domestic travel is visiting friends and relatives, however, the primary activities pursued meanwhile are resting and relaxation.

- Based on the results of empiric research it can be established that the travellers interviewed can be characterized according to their touristic motivations. Five touristic factors were extrapolated, namely: safe adventure, active idyll, economical, prestigious and cultural.

- The travellers interviewed can be characterized according to their lifestyle. Eight different lifestyles were extrapolated that fully correspond to the results of the VALS2 research. Hungarian travellers can be divided into eight groups according to their lifestyle characteristics, namely: Survivors, Experiencers, Believers, Innovators, Achievers, Strivers, Learners and Thinkers.

- Belonging to a particular lifestyle group has a diverse effect on the different touristic motivations:

- Survivors are motivated by low costs.

- Experiencers are motivated by prestige.

- Innovators are motivated by safe adventure, prestige and active idyll.

- Achievers are motivated by active idyll.

- Strivers are motivated by prestige.

- Learners are motivated by safe adventure.

- Thinkers do not show any dominant motivating factor. Based on the criteria of age, income, composition of household and frequency of travel, four clusters were identified, namely: impecunious tourists, country-trotters, childless young people and well-off middle-aged and senior citizens.

The travel behaviour of the defined homogenous clusters are influenced by different external factors, lifestyle characteristics and different touristic motivations.

\section{REFERENCES}

BELL, W. (1958): Social Choice, Life Style and Suburban Residence. The Suburban Community, 225-242.

BERKMAN, H. W. (1978): Consumer Behavior. Encino: Dickenson Publishing Company.

FREUD, S. (1923): Az ôs valami és az én. Budapest: Belső Egészség Kiadó.

HALBWACHS, M. (1971): A munkásosztály fogyasztói tendenciái. Budapest: Közgazdsági és Jogi Könyvkiadó.

HAVIGHURST, Robert - FEIGENBAUM, K. (1959): Leisure and Lifestyle. American Sociologist, 396-404.

HEXTER, M. B. (1916): Implications of a Standard of Living. American Journal of Sociology, 212 - 225.

KELLEY, E. (1963): Discussion. Chicago: American Marketing Association.
KOTLER, P. - KELLER, K.L. (2012): Marketingmenedzsment, Akadémiai Kiadó

LAWLER III, E. -H.-P. (1975): Behavior in organizations. New York: McGraw-Hill.

LAZER, W. (1963): Life Style Concepts and Marketing, in Toward Scientific Marketing. Chicago: American Marketing Association.

LEVY, S. (1963): Symbolism and Life Style. Chicago: American Marketing Association.

MITCHELL, A. (1983.): The nine american Lifestyles. New York: Macmillan Publishing Company.

RAINWATER, Lee - COLEMAN, Richard and HANDEL, GERALD. (1959): Workingman's Wife. New York: Oceana Publications.

SOBEL, M. (1981): Lifestyle and Social Structure. New York: Academic Press.

SUMMER, W. G. (1978): Népszokások (1936). Budapest: Gondolat Kiadó.

UTASI, Á. (1984): Életstílus csoportok, fogyasztási preferenciák . Budapest: Társadalomtudományi Intézet.

VEBLEN, T. (1975): A dologtalan osztály elmélete. Budapest: Közgazdasági és Jogi Könyvkiadó.

VERES, Z. -S. (2007): A marketing alapjai. Budapest: Perfekt Gazdasági Tanácsadó Oktató és Kiadó Zrt.

VERES, Zoltán - HOFFMANN, Márta - KOZÁK, Ákos. (2009): Bevezetés a piackutatásba. Akadémiai Kiadó: Budapest.

WEBER, M. (1964): The Theory of Social Economic Organisation. New York : The Free Press. 